\title{
OPTIMIZING LIGHTING PERFORMANCE OF UNDERGROUND ACCOMMODATION FOR MUSLIM PILGRIMS IN THE HOLLY CITIES
}

El-Hamouly, Nothiela, A.

Faculty of Engineering, Shubra, Banha University

\begin{abstract}
Muslims from all over the world have grown familiar with the traditional sight of the Holy land on mount Mina and Arafat during the Hajj for hundreds of years; the view of the tents established in those areas has become the memorable, architectural style and an unchangeable heritage legacy of this yearly Islamic event. However, following trends showing yearly exponential increase in the number of pilgrims recently imposed the greatest challenge for operators and organizers of the pilgrimage. A proposal addressing the inevitable need to preserve the historical urban/ architectural context of Mina and Arafat, underground accommodations represent an imminent solution. Optimizing natural lighting, ventilation and air conditioning for underground accommodations are key parameters for an efficient and sustainable upgrade for the holy lands. This paper presents a Parans fiber optics, natural light transfer system integration designed to enhance daylight performance in Hajj underground proposed habitational spaces. The proposed upgrade aims to align with both "LEED V4" and the "IES Daylight availability" standards. The natural "daylighting analysis" is performed using 'Radiance' for a generic room. Firstly, architectural design and technical system integration details are presented for the proposed underground accommodations. Secondly, the effect of fiber optics' system design on the space, lighting performance and energy efficiency is parametrically optimized and compared to the performance of traditional lighting, windows for a range of window to wall ratios (WWR) of equivalent mid-story high-rise south-facing spaces as reference base cases. Results demonstrate that Parans system integration achieved comparable results which meet "LEED v4" caliber and exceeds the "IES Daylight availability" criterions. Upgrading to multi-story underground residential spaces can maintain the historic contextual image of tents while
\end{abstract}


reducing heat transferred through the envelope by $200 \mathrm{kWh} / \mathrm{m}^{2}$ annually and reduce cooling loads components by $80 \%$ decreasing the $\mathrm{CO}^{2}$ emissions monthly by $500-600 \mathrm{~kg}$ per unit.

Keywords: Daylighting, Sustainability, Underground accommodation, Ventilation, Heritage Preservation, Green Urbanism.

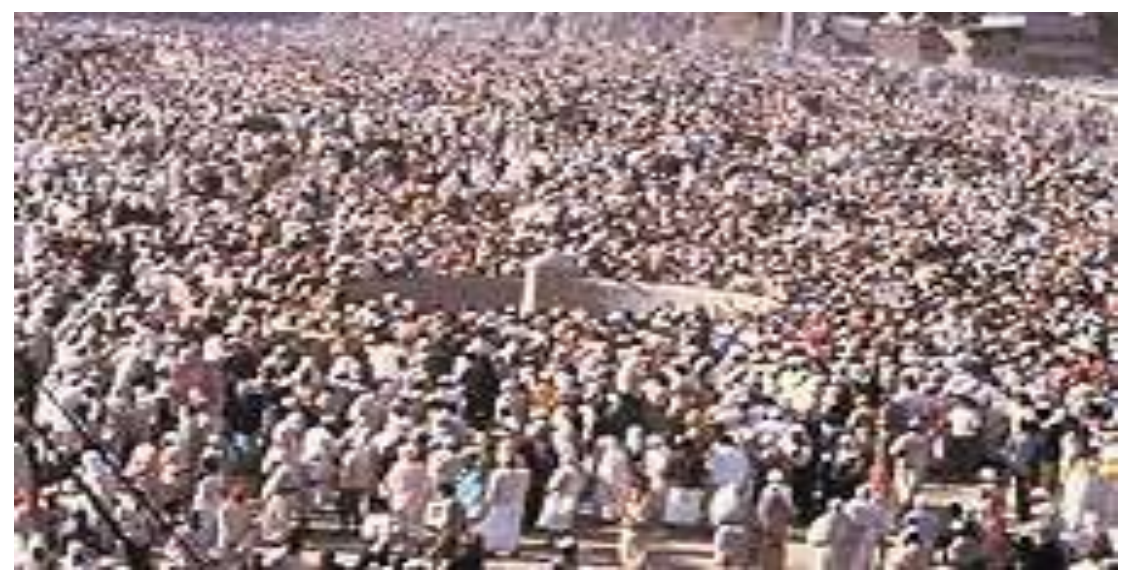

Fig (1): Al Jamrah al Kubra in Mina (Source: shafiqolbu)

\section{INTRODUCTION}

Every year and for three consecutive days after the 10th of Dhu'l-Hijjah, Muslim pilgrims stay at Mina for the ritual of stoning Ramy al-jāmārāt) (fig.1) and the worship of Allah; the ritual of stoning is an essential element of the pilgrimage and must be performed according to the pre-determined schedules. The ritual is performed seven times where pilgrims stone the pillar representing the devil while repeating "Bismillāh, Allāhu akbār" with every pebble thrown. "Bismillāh "means "in the name of God"; "Allāhu akbār" means "God is great". The ritual of shaving/ cutting of hair (Hālq/ Tāqseer), follows after the stoning of Al Jamrah al Kubra. Women, elderly and disabled individuals exempted from performing the stoning ritual themselves, instead, 
they stay in the tents, as accommodation, and the ritual is performed on their behalf by delegating individuals. Thereafter, the pilgrims end the state of Ihrām, The prohibitions imposed by Ihrām are suspended, and pilgrims may now shower, shave their heads (clip hair in case of females), and change into their normal clothes.

In those days, the ritual of accommodation within the tents in the Mina territory is regarded as an essential holy part in its well-known format. After fully covering the limited ground area by these tent structures (Fig.2), horizontal expansions to meet the growing needs is impossible.

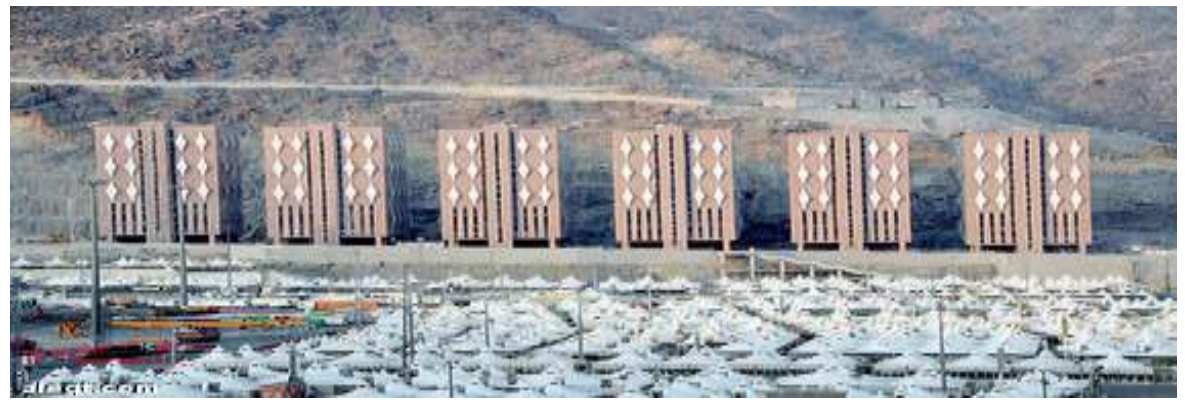

Fig.(2): Identity and character of Mina tents from 1433 years (Source: alriyadh.com)

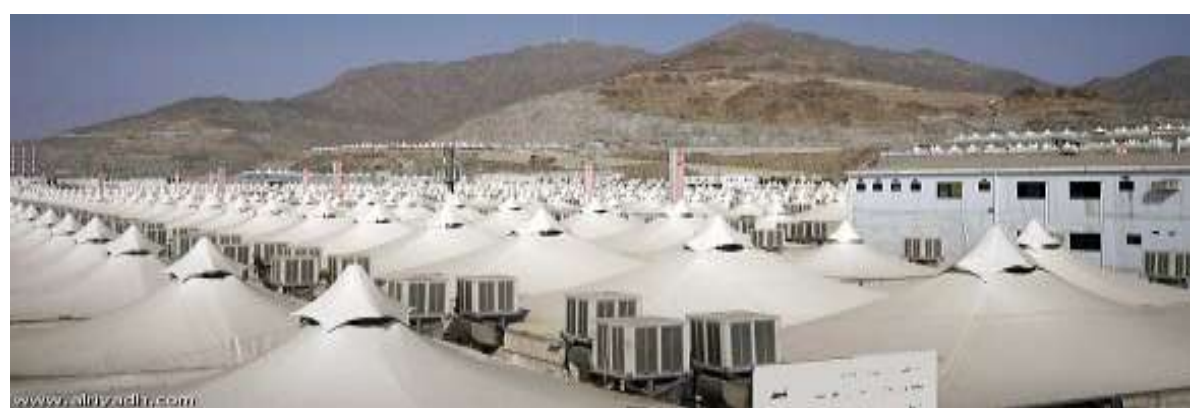

Fig.(3): Newly constructed Multi-story concrete buildings (Source: aleqt.com) 
On the one hand vertical expansion has been initiated in an attempt to increase the accommodation capacity (Fig.3). On the other hand, these expansions have altered the historic context and identity well-known since the days of the prophet PBUH for 1430 years. These vertical buildings have negatively affected the spiritual ambiance of the holly ritual leaving architects and planners in a dilemma, how the persistent number of tents which has fully occupied Mina, (fig.4) can house the yearly growing amount of pilgrims without the need to construct over-ground structures.

Historical background of Hajj: The Hajj is rooted from an ancient pilgrimage before the times of Prophet Muhammad PBUH in the 7th Century. The Hadith narrates the story of Abraham (Ibrahim), where the ritual of Hajj can be traced back to around 2000 BCE. Long before the prophecy time of Muhammad, and as an essential part of pilgrimage, once yearly people from all over the Arabian area would flock to Mecca. The faith and beliefs of these tribes were not of importance by then, even "Christian Arabs" likewise the pagans performed the pilgrimage. It was well-known about Muhammad PBUH even before receiving the revelation from god, that he would perform the "Umrah", a ritual that resembles Hajj. The year $631 \mathrm{CE}$, Muhammad drove his adherents from Medina to Mecca; it was the primary Hajj to be performed by Muslims only, and the main Hajj performed by Muhammad (Sahih Bukhari-hadith No 732-733, No 2941-2944, No 732-733). Starting here "Hajj" got to be one corner from the main five corners of Islam. 
Continuously increasing the demand for Accommodation in hajj days: Pilgrims at Mina execute "Ramy al-Jamarat", (fig.5) tossing no of gravels in meaning of their insubordination of the Devil also symbolizing the experience of "Abraham" of facing the challenge to give up his child as requested by God. Abraham refused at each of the three times the devil had challenged him. The three pillars denote the area of each refusal (Sahih Bukhari-hadith No 732-733, No 2941-2944, No 732-733. Peters, F. E. (1994). The stoning process starts going through all of the pillars with a specific number of gravels to be thrown (Juan E. Campo, ed. (2009). p. 282. Long, David E. (1979). p. 19). After performing this stoning ritual, the hajj must accommodate in Mina (fig.6) for a period of 72 hours for God's worship.

According to the announced numbers by the Royal Embassy of Saudi Arabia, foreign pilgrims performing Hajj per annually are as follows (Hajj stampede: Saudis face growing criticism over deaths". BBC. 25 September 2015. Long, David E. (1979)

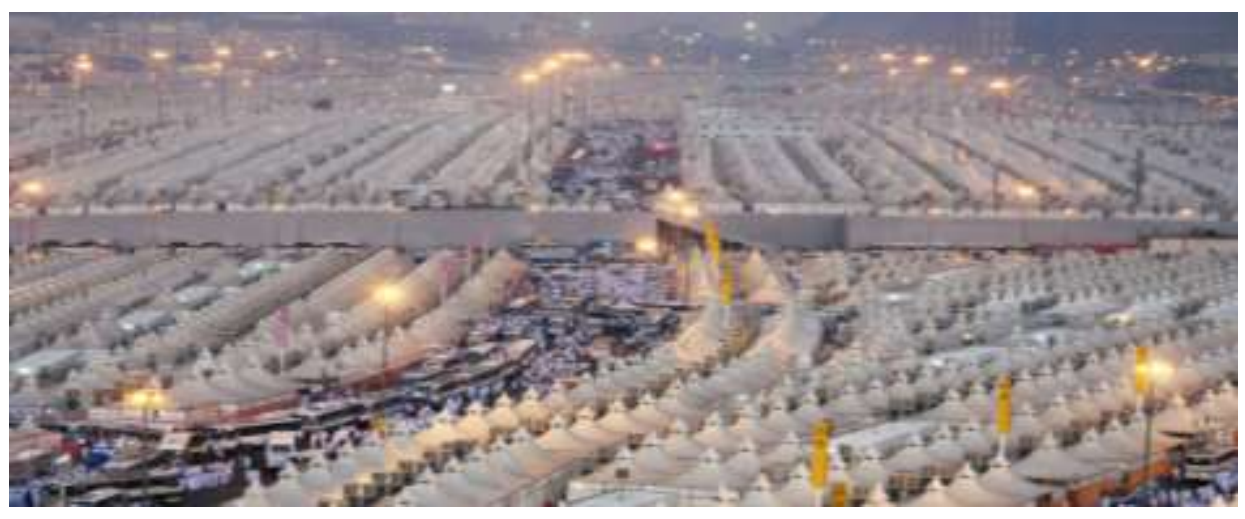

Fig.(4): Tents prepared in mina for pilgrims' accommodation with $\mathrm{A} / \mathrm{C}$ units, (Researcher). 
J. Environ. Sci.

Institute of Environmental Studies and Research - Ain Shams University

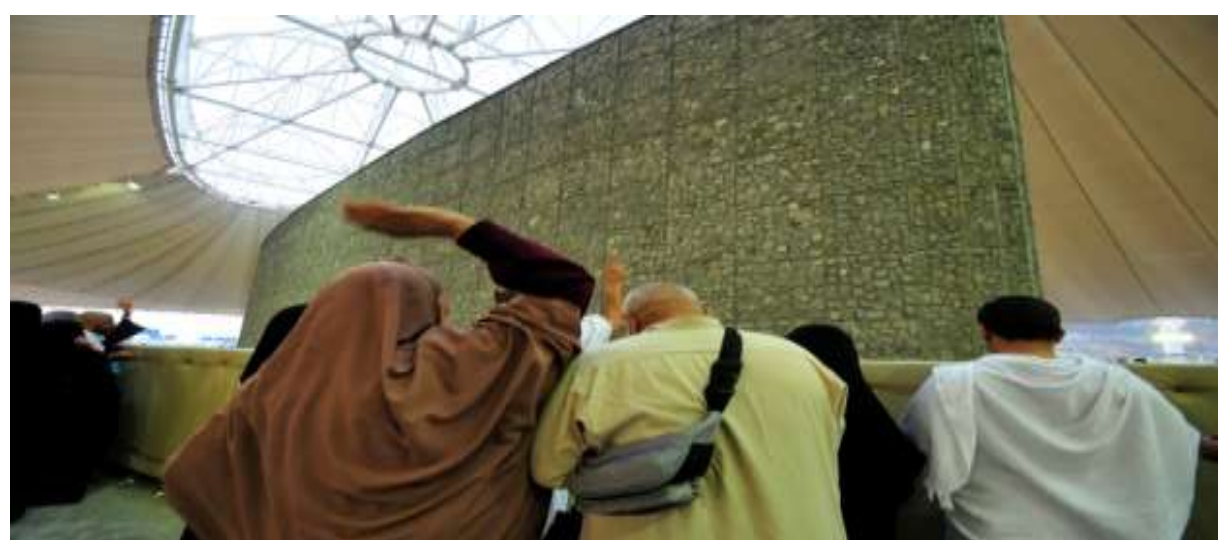

Fig.(5): Stoning of the devil, (Source: alriyadh.com, 2010)

Table (1): Number of pilgrims from 1920 to 2012 (Source: KSA Royal Embassy)

\begin{tabular}{|c|c|c|c|c|c||}
\hline year & $\begin{array}{c}\text { Number of } \\
\text { pilgrims }\end{array}$ & year & $\begin{array}{c}\text { Number of } \\
\text { pilgrims }\end{array}$ & year & $\begin{array}{c}\text { Number of } \\
\text { pilgrims }\end{array}$ \\
\hline \hline 1920 & 58,584 & 2001 & $1,363,992$ & 2010 & $2,521,000$ \\
\hline 1921 & 57,255 & 2005 & $1,534,759$ & 2011 & $2,789,399$ \\
\hline 1922 & 56,319 & 2006 & $1,654,407$ & 2012 & $2,927,717$ \\
\hline 1996 & $1,080,465$ & 2007 & $1,707,814$ & & \\
\hline 1997 & $1,168,591$ & 2008 & $1,829,841$ & & \\
\hline & $1,132,344$ & 2009 & $1,913,000$ & & \\
\hline
\end{tabular}

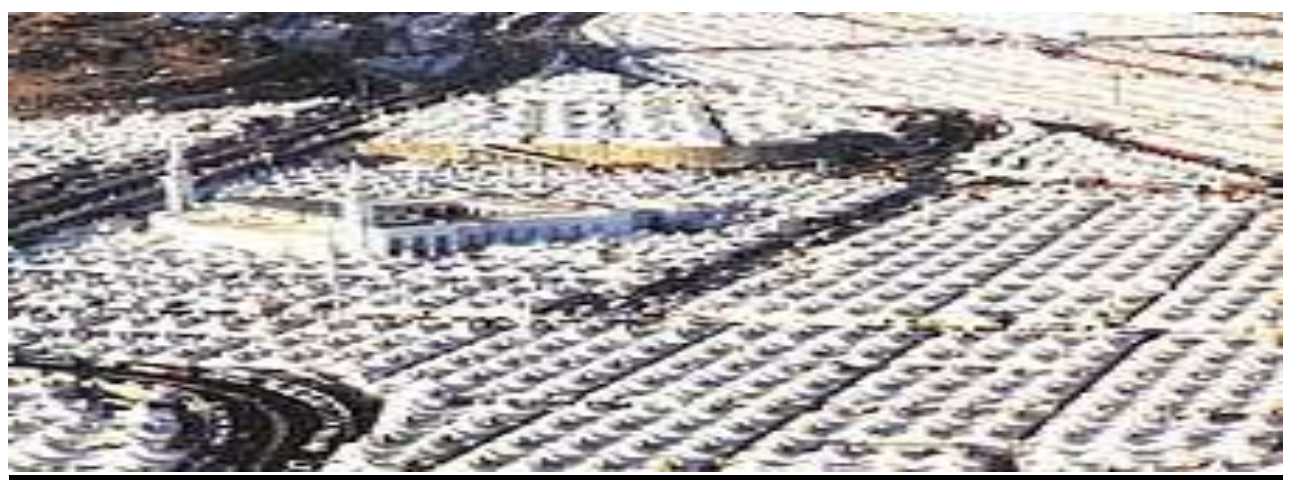

Fig. (6): City of tents, Mina (Source: alriyadh.com, 2010) 
By 2012, the aggregate number of pilgrims had reached 2,927,717, marking a 5 per cent increase in the total number recorded the year before. The number of pilgrims globally is continuously rising, for instance, the interim figures accessible for Hajj visas issued in the United States in 1996 doubled by 2000 .

The Google imagery shows the limited expansions and change in the region on a macro-scale due to the geography Figs (7-8).

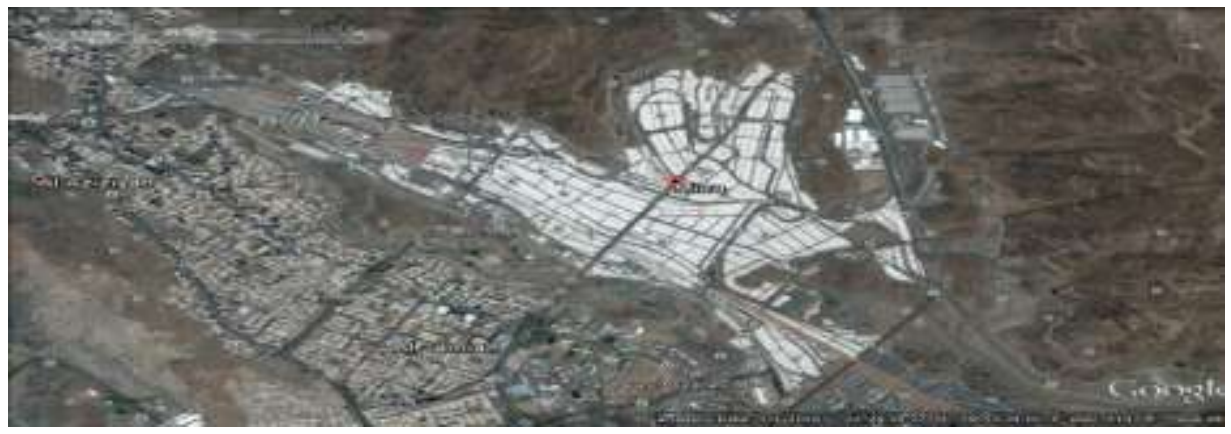

Fig. (7): City of tents, Mina 2004 (Source: Google earth, 2016)

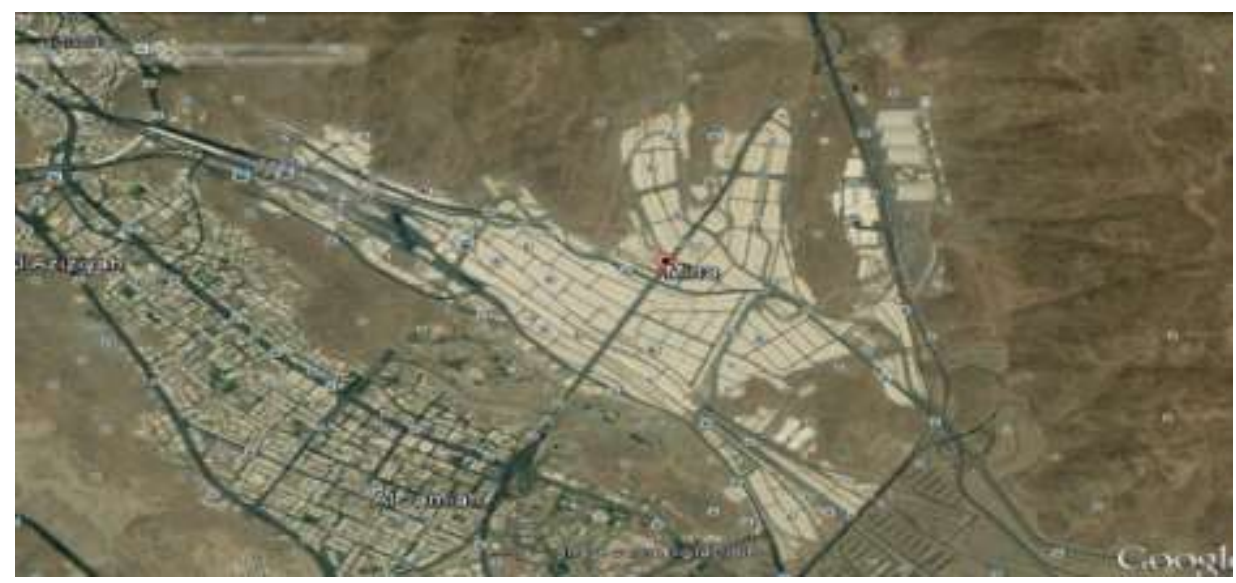

Fig. (8): City of tents, Mina 2015 (Source: Google earth, 2016) 
Proposed Approach to solve the problem by Sustainable way: A refined telecom system has been introduced to adapt the necessities of this ritual. Security and solace of pilgrims turned into noteworthy sympathy toward the powers, required by growing demand and numbers lately. Livability considerations are as well thought in the accommodation spaces. And with the increasing densities given the limited land space in Mina, the idea of underground accommodations has been always debarred by developers and urban planners due to the absence of natural light.

Daylight is the most important factor contributing in improving the indoor environmental quality and user comfort in residential spaces. Recent scientific research has proven the fact that humans 'subconsciously' are attracted to natural light. Moreover, Daylight is directly linked to better aesthetics, efficiency and general well-being. According to Reinhart, by maintaining the minimum illuminance level required, "the benefits of a carefully planned daylighting concept range from an improved lighting quality for the inhabitants all the way to energy savings by reduced artificial lighting consumption" (Reinhart, C. F., \& Wienold, J. (2011).). By integrating innovative lighting solutions within buildings, huge energy saving can be achieved, this has become recently viable through a diverse and wide range of daylighting transfusion strategies (Ramos, G., \& Ghisi, E. (2010).).

New Daylight Metrics: Following the last rating system for green buildings update, the "Leadership in Energy and Environmental Design system (LEED)", daylighting design forms one of the most important and rewarded rating criterion. To assess the quality of lighting in a given space, several new 
metrics have been validated for a higher accuracy and limited error margin. "Daylight autonomy (DA)" defined by Reinhart et al. as "the percentage of annual work hours during which all or part of a building's lighting needs can be met through daylighting alone" [29]. The fourth and latest version of LEED specifies two metrics to evaluate the performance of light in architectural spaces, the specified parameters allows a clear judgement for any space with sunlight accessibility through evaluating two criteria adopted form the IES:

Firstly, the illuminance abundance of natural sunlight "Spatial Daylight Autonomy (sDA)". Secondly, evaluating the visual comfort of light performance within the same space through evaluating "excessive sunlight penetration" this metric is known as "Annual Sun Exposure (ASE)" (.IES. (2012).), together the aforementioned tests assess daylight performance in different designed spaces. sDA identifies the percentage of space receiving sufficient daylight, in the case of residential functions, The IES specifies in the evaluation rules that for a space to be deemed well-lit, the tests should show "(sDA 300 lux / 50\% of the annual occupied hours) for at least $55 \%$ of the floor area". The fact that sDA does not have a maximum, accordingly, ASE metric gives a clear picture on the percentage of space area where visual glare will occur due to severe contrast or heavy exposure to direct sunlight rays. The evaluation rules with IES standards and the USGBC "ASE measures the percentage of floor area that receives at least 1000 lux for at least 250 occupied hours per year [19], this must not exceed $10 \%$ of floor area to be deemed successful" (USGBC. (2013).). 
Fiber Optic lighting solution: Due to the lack of natural lighting, underground spaces had been regarded as unpleasant spaces for decades. Since the inception of Parans fiber optic natural lighting solution in 1996, the technology has changed this perception of underground spaces. Designers were able to integrate the technology, hence, achieving natural lighting benchmarks through a zero energy system, moreover, saving millions of dollars in lighting expenses. Light Intake through Fiber optics technology presents a an integral green method to transfer sun rays to internal zones concealed within a structure or underground, a design problematic that was not previously feasible. For deep planning projects, this technology allowed spaces to be naturally lit, however, for natural lit spaces, the technology permits huge power bill cut downs by providing light during day time and turning off auxiliary artificial lighting.

Parans fiber optic systems aided a wide spectrum of building typologies to achieve LEED sustainable ratings. The unique technology of Parans system uses the parallel rays of direct sunlight that are focused using lenses. A variety of light receivers different in size and capacity of lenses, each lens projects light rays to the plastic fiber terminals. Fibers are concealed in a braid for isolation and safeguarding they are provided in a variety of lengths ranging from fifteen to sixty five feet in length. Fibers act as the rails or trays that coveys lighting from sun rays (Swift P D and Smith G B (1995).). Parans systems collects light with a luminance power up to 6000 lumen per collector. A fraction of illuminance is taken in and discarded per unit length of these fiber "optical fiber braids". Since the Parans solar light system works on 
parallel sun light, direct sunlight is essential to the operation of the system. However, on partly cloudy days, the system emits a satisfactory dynamic light which gives a natural feel to the occupants, as sky is covered or clear light rays are not abundant (receptors are in shade). On cloudy days and at night operation hours, synthetic lights are used. Parans collector system follows the sun motion over all sunshine hours of the day. As per the LEED recommendations UV-radiation is not allowed through the Parans system for a better indoor environment. This avoids human skin undesired tan, moreover, avoiding bleach of furniture and other surfaces. The Parans system as well, filters out Infrared spectrum, hence decreasing heat transfer. Combined with the well-sheltered underground spaces, Parans systems help achieve the near zero energy goal by reducing heating/ cooling loads to minimal specially when cooling loads are 40 percent of the structure's energy demands in the arid weather of KSA. The proposal for underground accommodations utilizes materials which are in compliance with the LEED v4 requirements.

\section{METHODOLOGY}

This study aims to design and optimize a natural daylighting solution for the proposed underground accommodation areas in the Holy land in Mina. The optimized design aims to present a sustainable and healthy accommodation environment. For the purpose of massive scale urban upgrade within the objective of this study, the methodology should provide a validated estimate for the lighting performance of all proposed units. Moreover, to identify ideal size/power of light reflection system to meet "LEED V4 
daylighting standards" and "IES Daylight availability". Firstly, the customary mathematical model is outlined as a preliminary benchmark for calculations. Secondly, research capitalizes on the use of practical fast "parametric optimization approach" to define the "near-optimum" System design arrangement sufficient for a generic dwelling space in Mina, Kingdom of Saudi Arabia. The simulation strategy employed in this study is divided into two successive stages.

First stage performs a full light access study and "daylighting performance" analysis for a base case room with specific size and window properties, while second phase is conducted using parametric optimization of a Parans Fiber Optic Skylight system parameters to achieve the near-optimum daylighting acceptability by "LEED v4" standards. The twin phase methodology utilizes "Diva for Rhino (a plug-in for Rhinoceros modelling software)" as a verified simulation tool.

Verification Calculation model and Daylight Simulation Tools: Green building rating systems use daylight simulation as a reliable design optimization process (Gasiu, A., \& Reinhart, C. F. (2008).). On the one hand, most existing simulation tools involve extended time and requires massive computing power to reach optimal designs, every iteration often involves manual interference to remodel the transformations and system modifications. On the other hand, these simulation techniques explains the factors affecting the "daylighting performance" [33]. Several plug-ins have been developed for the Grasshopper platform which is a visual coding tool that connect the 
Rhinoceros 3D geometry to simulation software (McNeel, R. (2010). Rhino. Retrieved June 24, (2014)).

In this study for the optimization process, several "Daylight Availability evaluation levels" are utilized: "daylit", "partially daylit" and "over lit" zones. Definitions are in accordance with the "IES standards", "daylit areas are grid nodes that receive satisfactory daylight no less than half of the yearround occupancy hours. Consequently, partially daylit areas are grid nodes that do not receive satisfactory daylight no less than half of the year-round occupancy hours. Over lit areas are grid nodes that receive over required daylight where 10 times the target Illuminance was reached for no less than $5 \%$ of the year-round occupancy hours" (Reinhart, C. F., \& Wienold, J. (2011).).

To calculate the daylighting performance levels within the space, both, Natural and artificial light calculation methods are utilized as the proposed underground space relies "partially" on each according to the "sky condition". The evaluated accommodation space is allocated into a sum of equivalent areas (grid patches), square proportions are the optimal. The "illuminance levels" (E) at the center of each area (patch) is measured and the mean value calculated.

$\mathrm{E}_{\text {total }}=\mathrm{E}_{\text {direct }}+\mathrm{E}_{\text {ref.ceiling }}+\mathrm{E}_{\text {ref.walls }}$

$\mathrm{E}=\mathrm{I} / \mathrm{d}^{2} \cos \theta$

Where $\mathrm{I}=$ Intensity of source; $\mathrm{d}=$ distance from luminaire to the grid calculation point; $\theta=$ angle of incidence. To calculate the "Room Index" (RI) 
$\mathrm{RI}=\mathrm{L} \times \mathrm{W}$

$\mathrm{H}_{\text {mount }}(\mathrm{L}+\mathrm{W})$

Where $\mathrm{L}=$ inner wall length; $\mathrm{W}=$ inner edge width; $\mathrm{H}_{\text {mount }}=$ the mounting height of the light fixtures above the "horizontal working plane" assumed $0.8 \mathrm{~m}$ above floor level. The following table gives an estimate for the minimum number of calculation/ measurement points within a space.

Table (2): Minimum Number of measurement points for space (Source: IES)

\begin{tabular}{|c|c|}
\hline Room Index & Minimum number of measurement points \\
\hline \hline$<1$ & 9 \\
\hline 1 and $<2$ & 16 \\
\hline 2 and $<3$ & 25 \\
$=>3$ & 36 \\
\hline
\end{tabular}

For natural light calculation a "daylight factor" is utilized for calculation where the this ratio determines the relation between light level inside a structure to the light level outside the structure

$\mathrm{DF}=\left(\mathrm{E}_{\text {in }} / \mathrm{E}_{\text {out }}\right) \times 100 \%$

Where, $\mathrm{E}_{\text {in }}=$ daylight illuminance at grid point on plane, $\mathrm{E}_{\text {out }}=$ "simultaneous outdoor illuminance on a horizontal plane from an unobstructed hemisphere of overcast sky". 


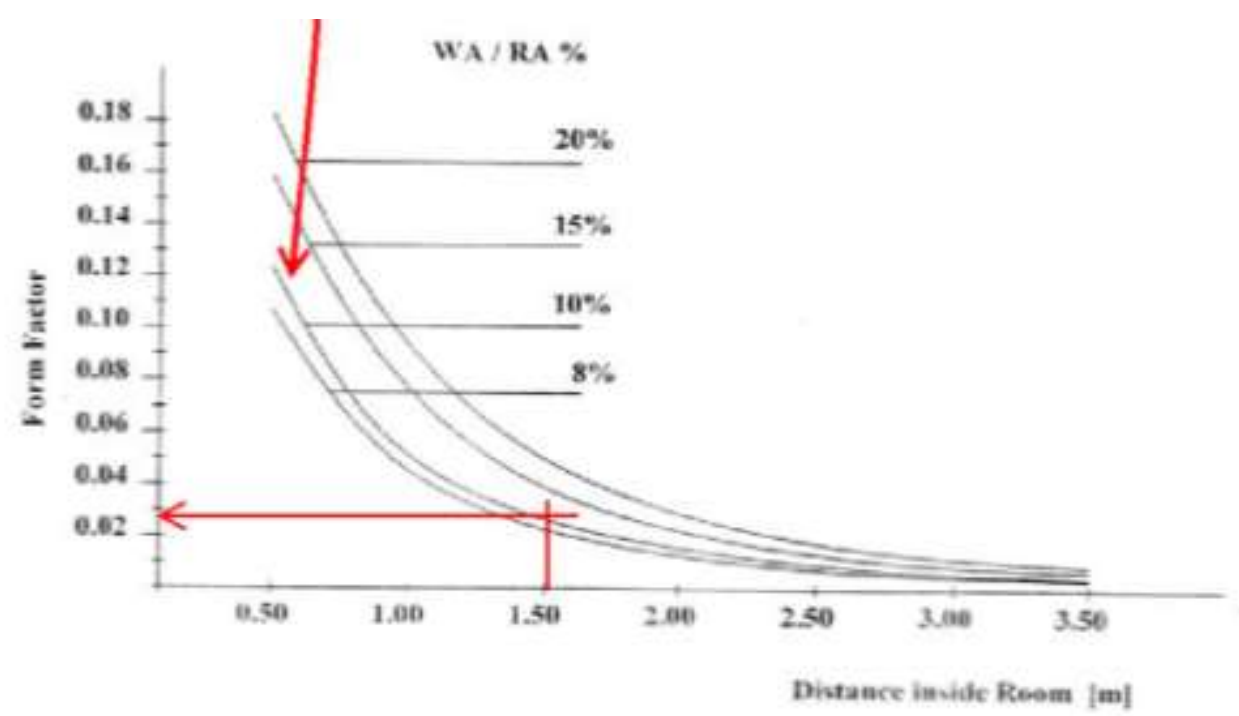

Form [view] factor between Reference position and Window x 0.54

In simulation calculations a similar patch method based on "The Nusselt analog" is utilized to measure form factors for complicated surfaces, by photographing them through a suitable sky patch. This is the case with "Design Iterate Validate Adapt (DIVA) for Rhinoceros 3D", the plugin tool delivers the "Grasshopper" platform with "Radiance and DAYSIM software". "Radiance and DAYSIM" use "a reverse ray-tracing algorithm based on the physical behavior of light in a volumetric, three-dimensional model which accurately represents reality". 
J. Environ. Sci.

Institute of Environmental Studies and Research - Ain Shams University

The calculation grid presented is fixed for the simulations as well to validate the results
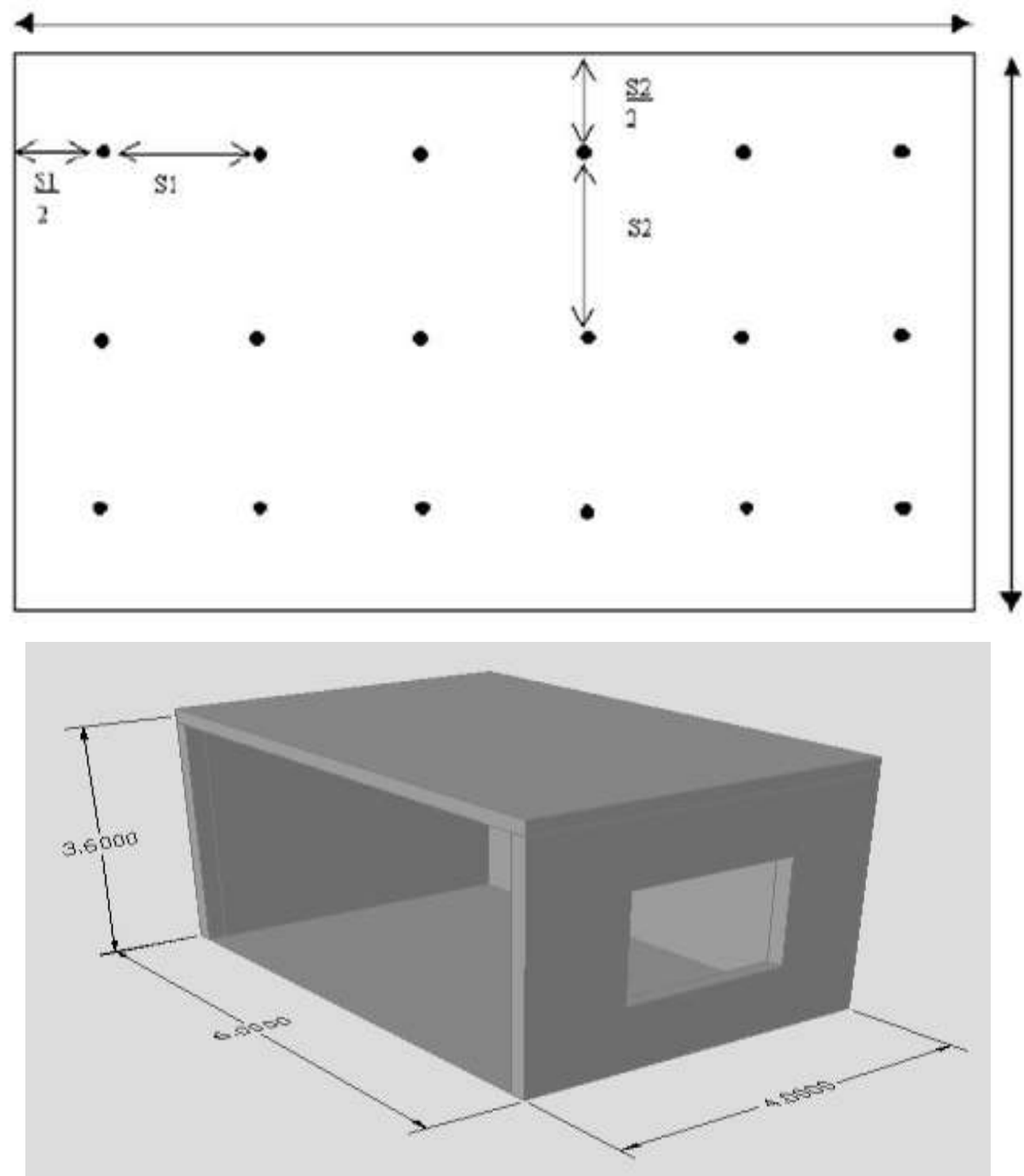

Fig.(9): Base Case Room (Researcher) 
Table (3): Base Case specifications

\begin{tabular}{|c|c|c|c|}
\hline Variables & Design Variables & & $\begin{array}{c}\text { Performance } \\
\text { Categories }\end{array}$ \\
\hline \multirow{3}{*}{ Window } & "Window to wall ratio (WWR: $10 \%-90 \%$ ) & \multirow{7}{*}{$\begin{array}{l}\text { Radiance/ } \\
\text { Daysim } \\
\text { annual } \\
\text { lighting } \\
\text { simulation }\end{array}$} & \multirow{4}{*}{$\begin{array}{l}\text { Spatial Daylight } \\
\text { Autonomy } \\
\text { (sDA) }\end{array}$} \\
\hline & Metal with thermal break & & \\
\hline & U-Value: $3.4068 \quad$ SHGC: 0.62 & & \\
\hline Glazing & Double Clear, Visible Transmittance: 0.63 & & \\
\hline Walls & $\begin{array}{l}\text { Reflectance: Walls } 60 \% \text {, } \\
\text { Ceiling } 80 \% \text {, Floor } 30 \%\end{array}$ & & \multirow{3}{*}{$\begin{array}{l}\text { Annual Sun } \\
\text { Exposure } \\
\text { (ASE) }\end{array}$} \\
\hline \multirow[b]{2}{*}{ Room } & Window Sill: $1 \mathrm{~m}-0.5 \mathrm{~m}$ & & \\
\hline & $\begin{array}{c}\text { Room Height: } 3.6 \mathrm{~m} \\
\text { Room Dimensions: W } 4 \mathrm{~m}, \mathrm{~L} 6 \mathrm{~m} \text {, South } \\
\text { façade opening }\end{array}$ & & \\
\hline
\end{tabular}

Base Case Identification: For this study, a naturally-lit space has been defined as a $4 \mathrm{~m}$ by $6 \mathrm{~m}$ south oriented room (Fig.9). The base case room model is constructed on an assumed indoor residential space on the first floor, located in Mina, KSA. A range of window to wall ratios (WWR) for the south edge wall is tested (WWR from 10 to 90 ) to identify the minimal adequate WWR for comparison with the proposed Parans Fiber Optic system in the optimization phase. Similar research utilizing validated simulation tools allows the simulation results a minor error margin in calculations, this depends on a several reasons; firstly modelling accommodation space details, as well as the geometrical and photometrical properties used by the simulation engine. For reasons of achieving best real-time light evaluation, fiber optic system is compared to existing real-life installed similar systems in detail. The properties of the accommodation space, glazing type and window are fully described in Table 3.

System Design: Mina, known as the 'tent city' lies between the Holy City of Makah and Muzdalifah. All pilgrims must stay in Mina for three days, the city 
has earned its reputation throughout years the history of hajj as a contextual landmark easily relatable to the pilgrims from 1433 years till date. To maintain this historic cognitive link, underground accommodation has been proposed to house the increasing number of pilgrims yearly. The underground constructed floors are to be concealed under the historic tents deep in ground. As constructed by the researcher Fig. 10 shows a cross section through the underground accommodation spaces, illustrating the integrated Parans Fiber Optic system within the hollow structural columns.

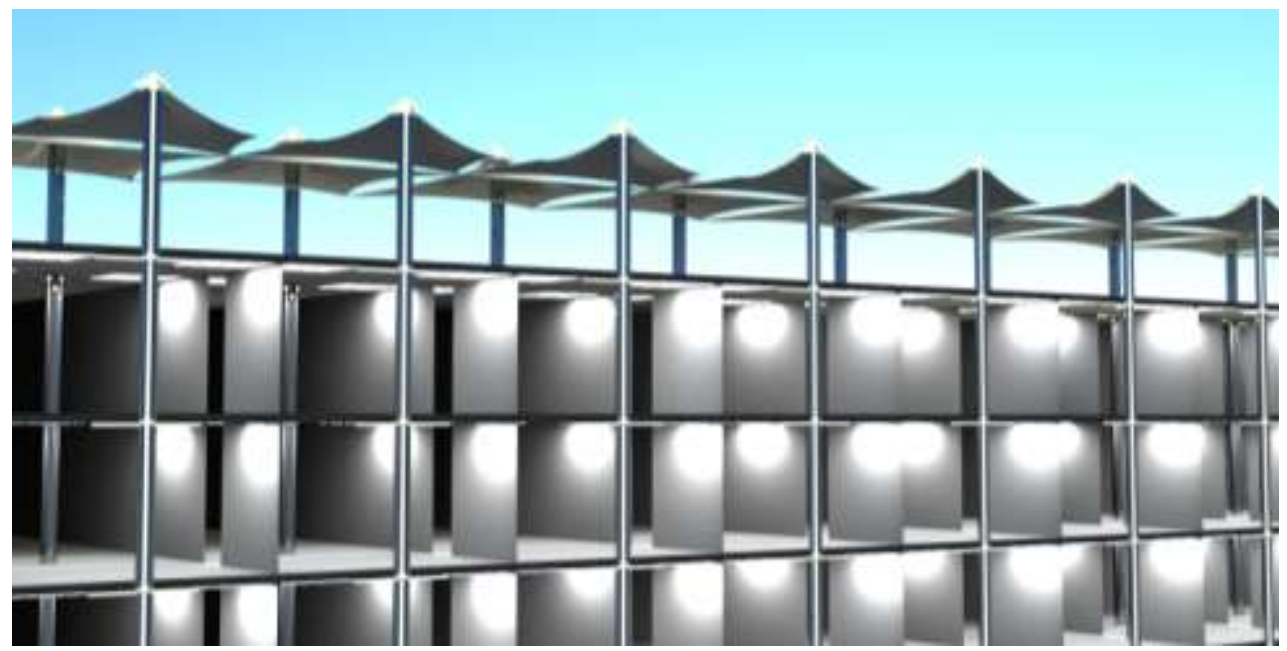

Fig. (10): Vertical section through underground accommodation spaces under the tents (Researcher)

The researchers' design demonstrated in (Fig. 11) shows the relationship between over-ground tents and underground floors, the schematic section illustrates how sunlight is transferred during the day from top tent headers to be transformed by fiber optics through the hollow core section of structural columns which supports the underground slabs. 


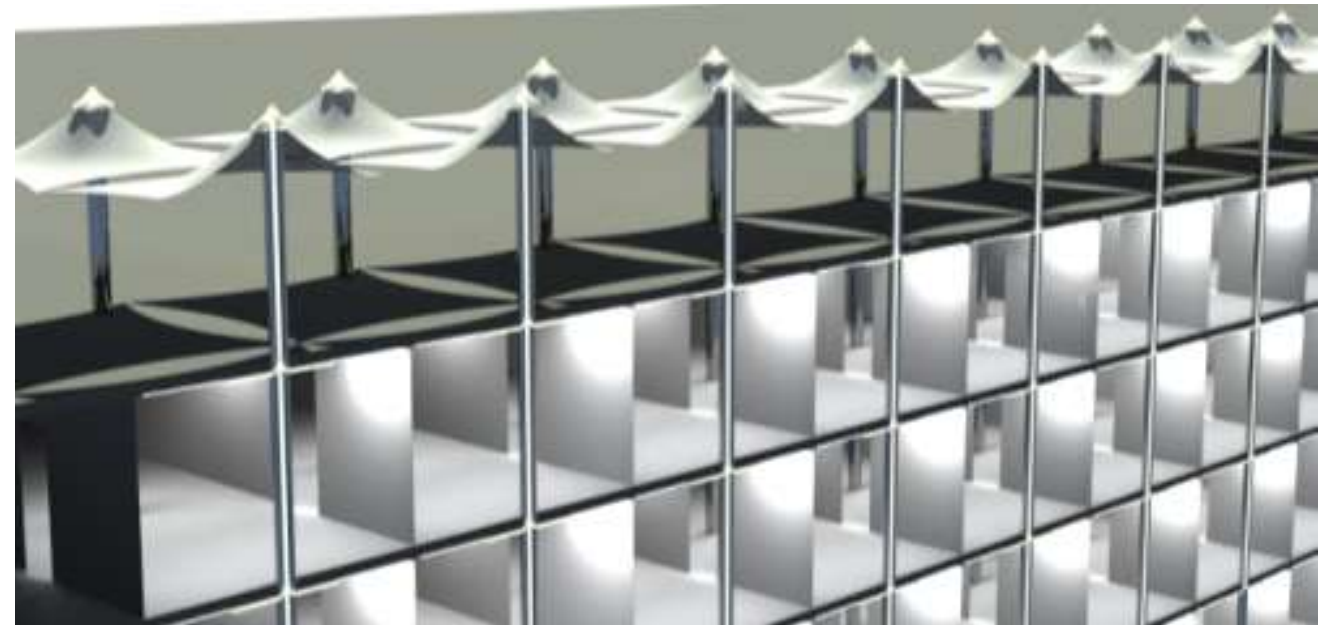

Fig. (11): Vertical section illustrating over-ground tents relation to underground floors (Researcher)

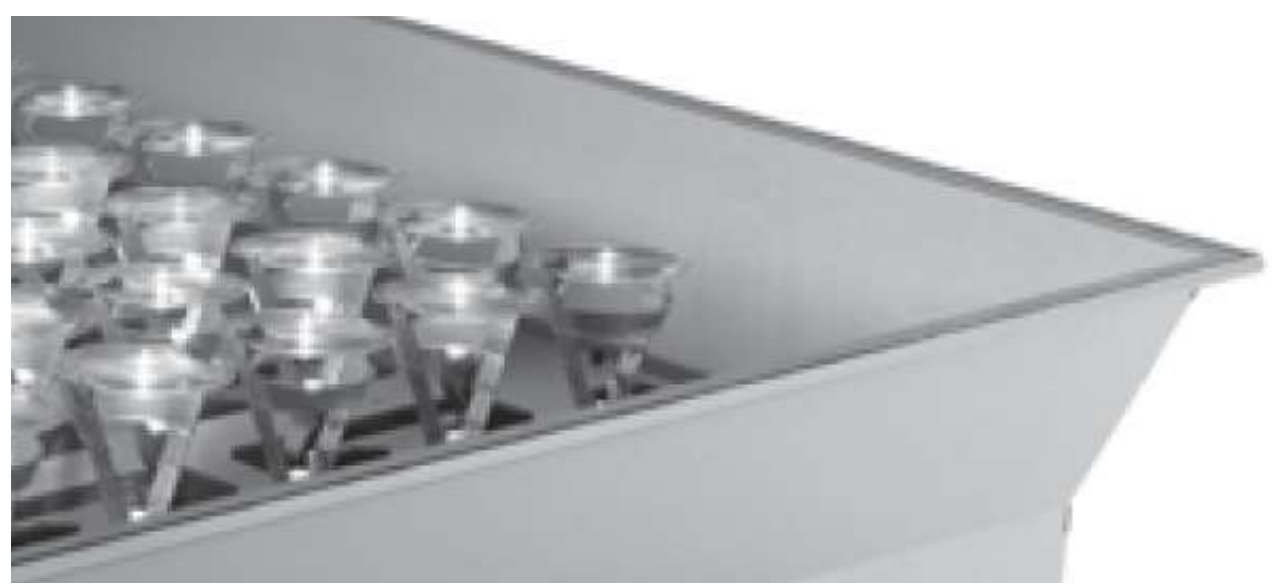

Fig. (12): Parans solar collecting lenses on standard panel (Source: HUVCO)

The Parans fiber optic skylight system has been modified in this study integrating within the structural system of the proposed underground accommodation spaces. The external light harvesting terminal pane is constructed of 64 "Fresnel sun-tracking lenses" (Fig. 12) this collecting pane 
is implemented in a unique design by the researchers to be shaped in the head part of the tent (Fig. 13, 14.).

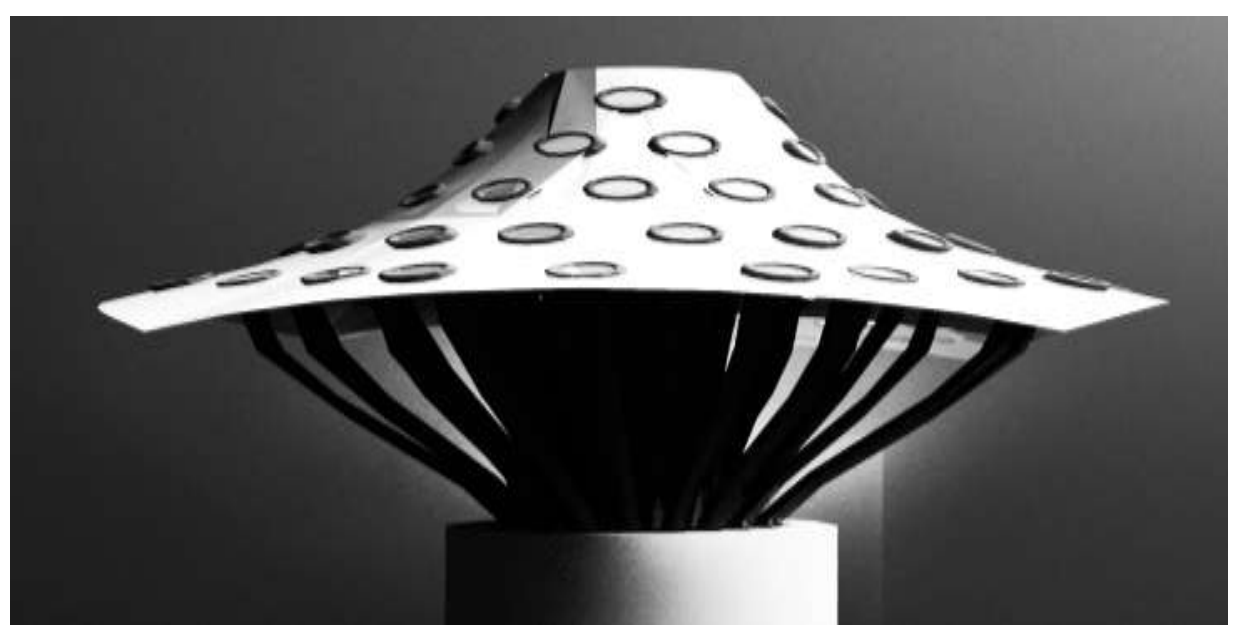

Fig.(13): Parans solar collecting lenses on Tent head modification (Researcher)

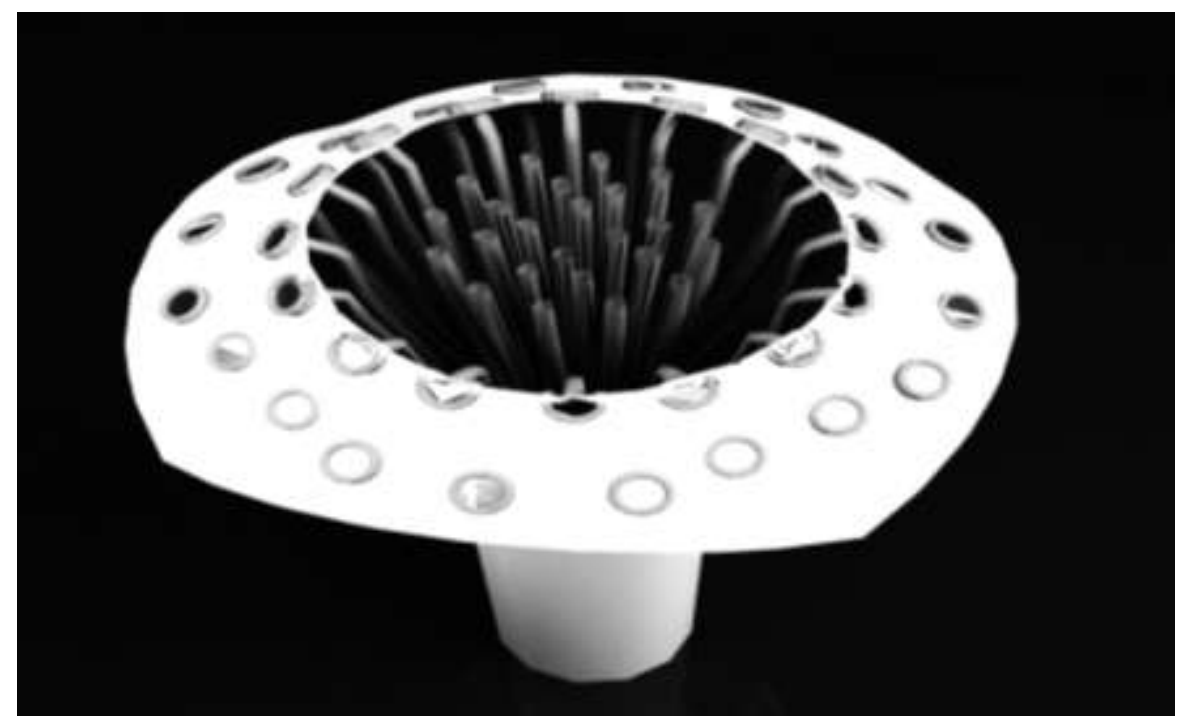

Fig.(14): (right) Sectional top view of Tent head modification (Researcher) 
The focused sunlight collected from the tent header is directed into a fiber optic element (cable) (Fig. 15) fiber optic strands are braided into a 0.6 $\mathrm{cm}$ thickness single manacle. Each harvesting panel exports light through four manacles, the 60 feet cables are bundled in the hollow cylindrical columns system under the tent head (Fig.16). The cables following through the columns are routed through walls, ceilings and bent around obstructions (Fig. 17).
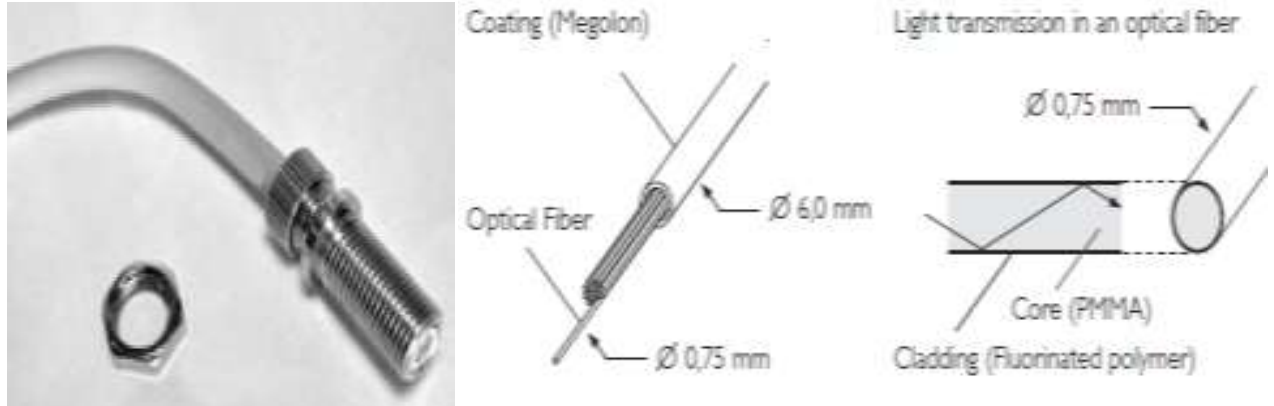

Fig. (15): Optical fiber cables assembly (HUVCO)

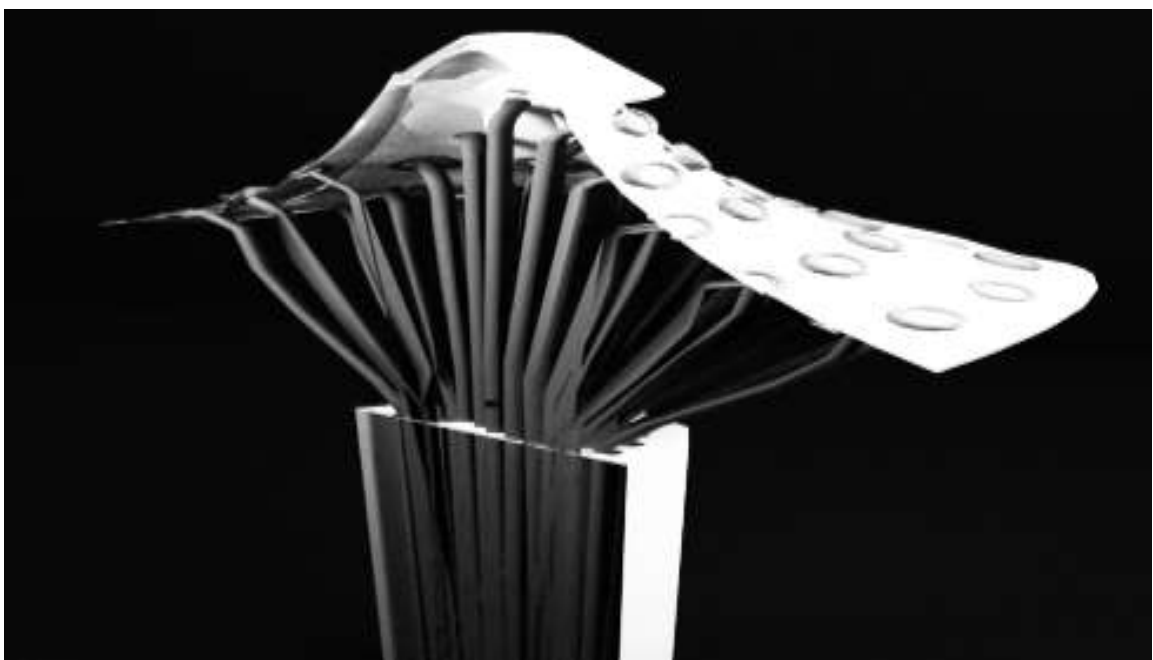

Fig. (16): Sectional view of the designed tent head light collector with fiber optic bundle cables integrated within structural columns (Researcher) 


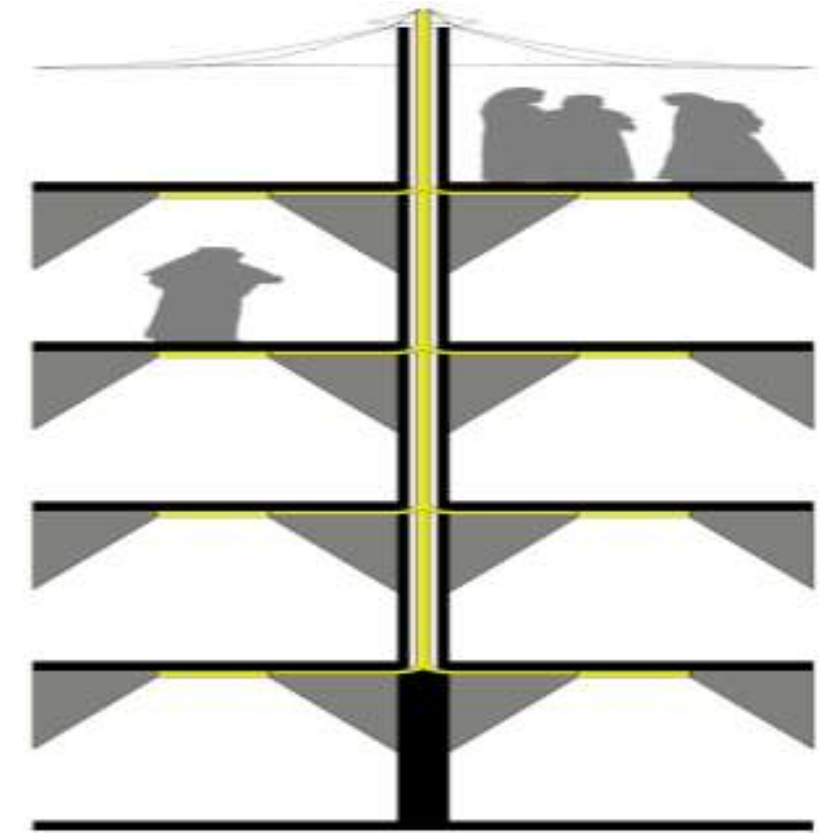

Fig.(17): Schematic section through the underground floors proposed showing the fiber optic cables routed through walls and ceilings (Researcher)

\section{Simulations \& optimization:}

Phase 1: Base Case Simulation: For the first simulations phase, the base cases are simulated for Daylight Availability in a range of WWR iterations from 10 to 90 with a step of 10 Table 4 . The base case simulations illustrate sufficient daylight autonomy at a minimal WWR of 50\%, however at greater WWR, the over-lit areas due to ASE of more than 250 hours annually increases around the opening area.

These over-lit areas cause glare and visual discomfort. In compliance with Daylight availability (DA) standards and LEED V4 daylighting requirements, WWR 50\% is taken as a reference for phase two Parans system optimization. 
El-Hamouly, Notheila, A.

Table (4): Base case daylight availability performance per WWR (Researcher)

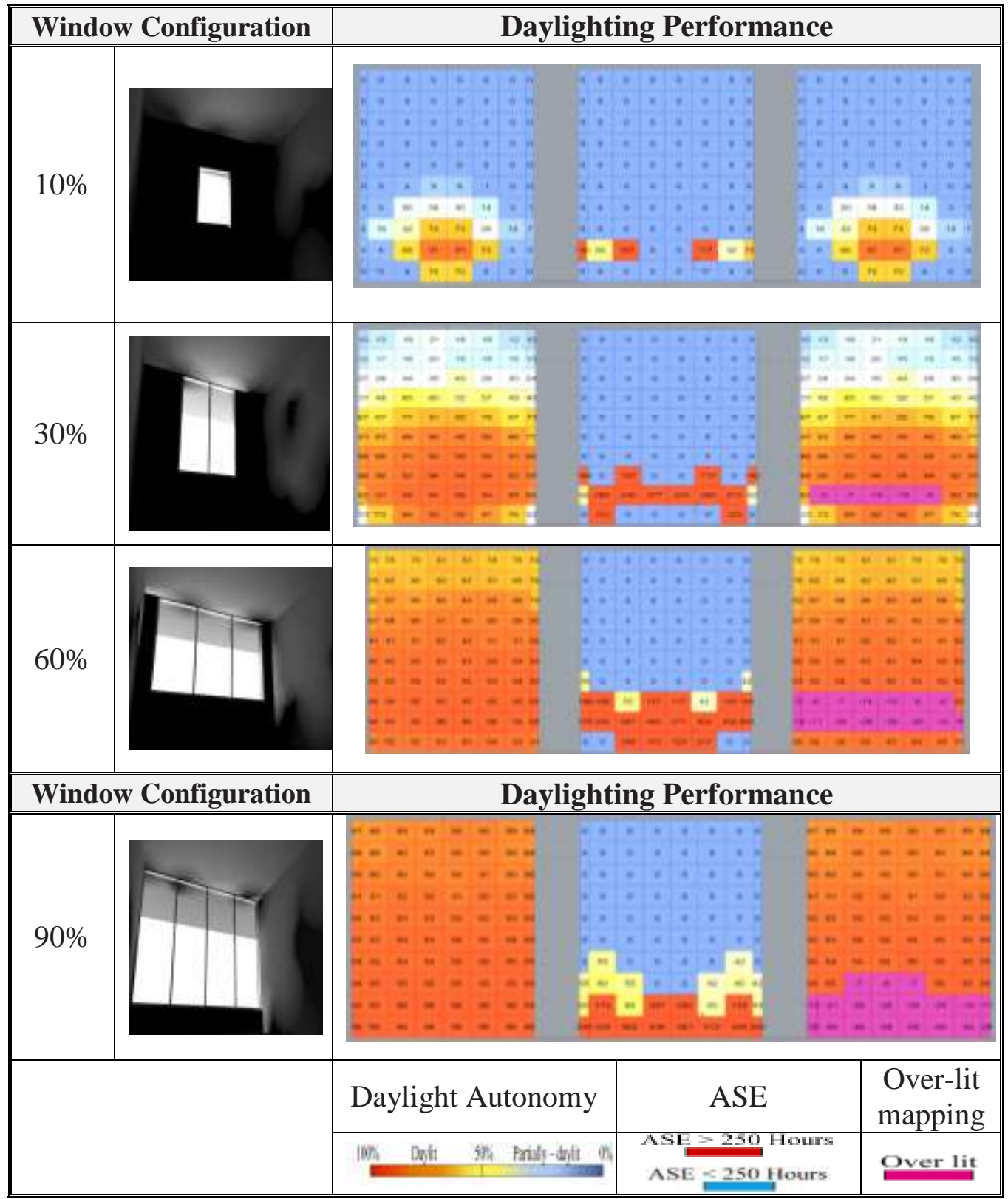

Vol. 41, No.3, March 2018 
J. Environ. Sci.

Institute of Environmental Studies and Research - Ain Shams University 
Phase 2: Parans Fiber Optic System Optimization: As pre-mentioned in the literature, each fiber optic cable braid conveys natural illumination to a terminal inner luminary; alternatively, several cables pooled in a single luminary can be adopted. For this study a "hybrid fixture" is used, this fixture combines daylight with the possibility of artificial light emitter into a single outlet. The "hybrid fixture" is in compliance with LEED standards for energy efficiency since it is coupled to a dimmer that autonomously turns off auxiliary artificial lights in case of the daylight from harvesting terminal surpasses a pre-determined limit. The fixture is also provided in several luminary types such as directional lights (Fig. 18).

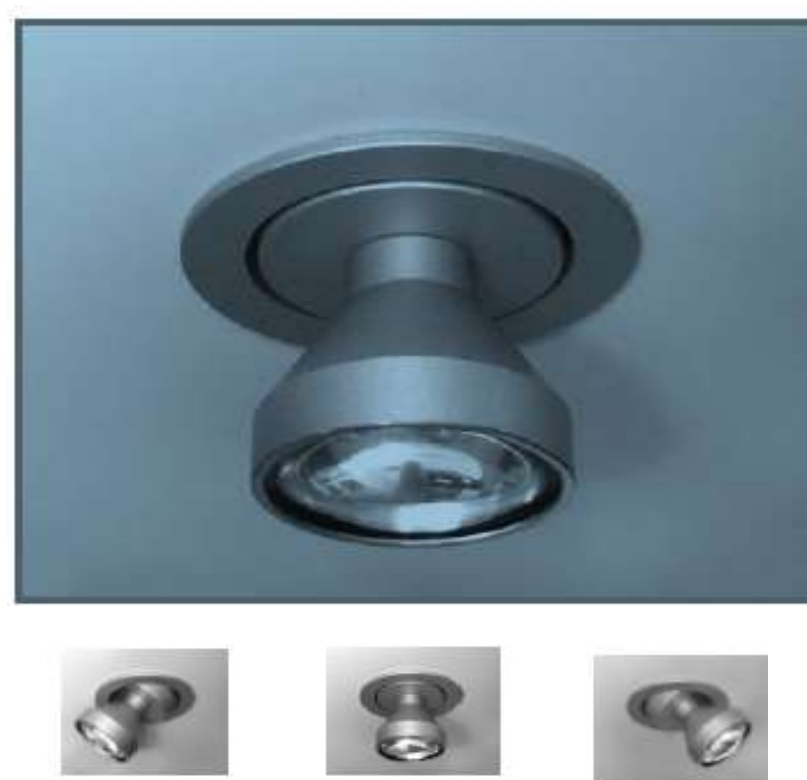

Fig.(18): Parans directional spotlight fixture. (HUVCO) 
J. Environ. Sci.

Institute of Environmental Studies and Research - Ain Shams University

The design scheme for lighting the planned underground accommodations in Mina is reliant on the harmonized, comfortable light fixtures position and arrangement in the rooms. To optimize such fixture arrangement and evaluate the performance a parametric algorithm is utilized to test several alternatives through annual simulations. The optimization algorithm aims to eliminate over-lit grid nodes and reach a normalized arrangement of fixtures in space to avoid under-lit spots. For the second simulations phase, the base cases is simulated for Daylight Availability without the window, however, Parans optic system is assumed at different fixture count/ positions. To simulate the daylight effect, the model is mimicking a skylight in the room, hence, acquiring accurate performance estimation to real-life (Table 4). 
El-Hamouly, Notheila, A.

Table (5): Parans system daylight availability performance optimization (Researcher)

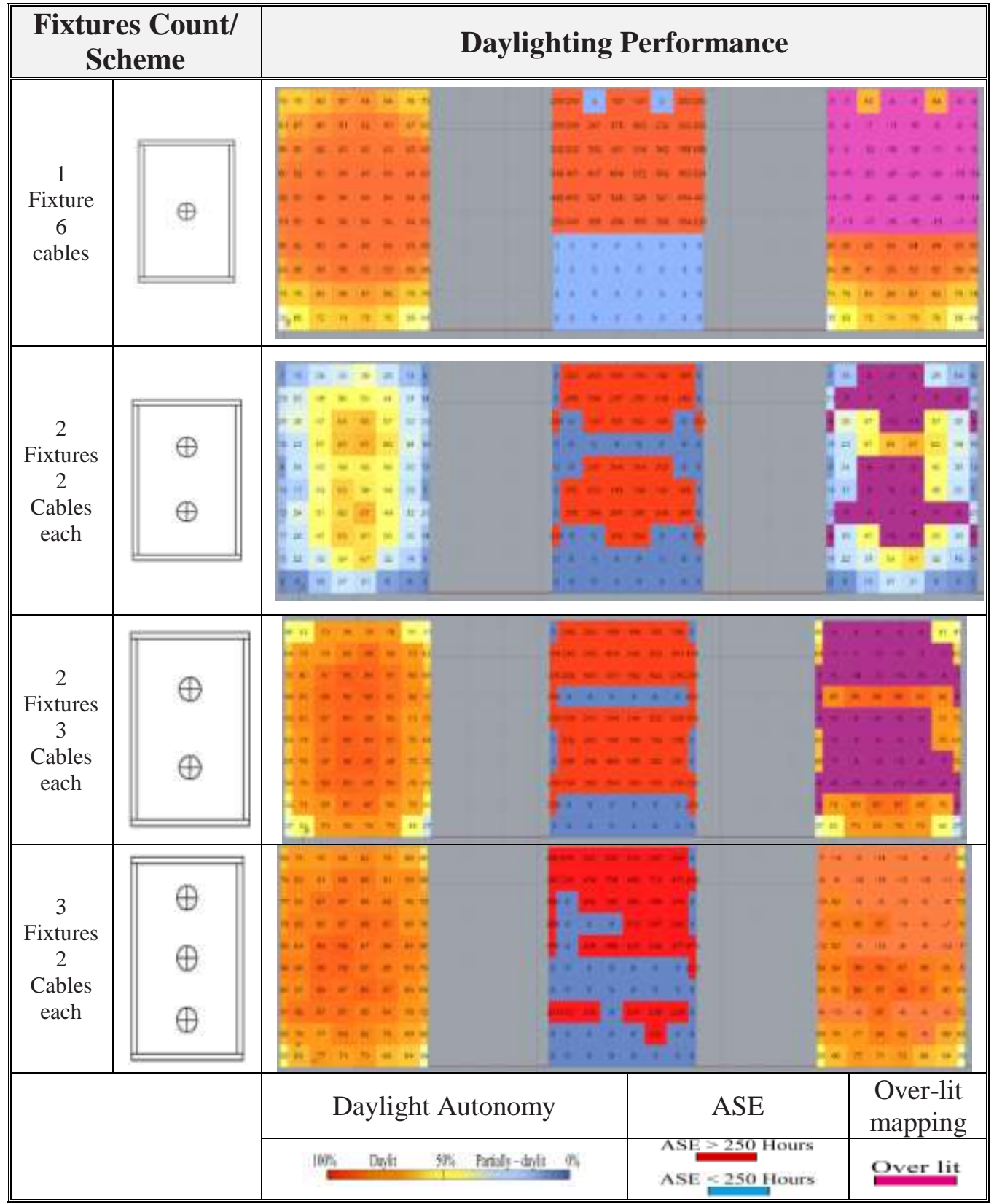

Vol. 41, No.3, March 2018 
The optimization simulations illustrate sufficient daylight autonomy at all schemes, however at three lighting fixtures with minimal illuminance power, the over-lit areas due to ASE of more than 250 hours annually are avoided. At lower fixtures count, higher illuminance power causes over-lit areas in the room, which resembles the base case, however the location of over-lit spots is under the fixtures.

\section{DISCUSSION \& CONCLUSION}

This study presents a hybrid optic fiber lighting system design solution for underground accommodation in the Mina area. It is concluded from the study and discussion that the most sustainable and energy saving approach to accommodate the evergrowing demand of pilgrims annualy is by introducing "underground dewelling levels" underneath the exisiting site fully covered by tensile tent units. The proposed solution succeeded in preserving area's heritage and contextual visual image which has been well memorized for hundreds of years. The new urban strategy is coupled with an efficient lighting system. The lighting system design is motivated by achieving green standards of "daylight performance" aided by validated simulation tools and exhaustive optimization techniques. The simulations were performed for a generic south facing frontage of a typical accommodation room similar to the existing tents in Mina, KSA.

To optimize the lighting scheme design, a two stage methodology is adopted, the first phase reaches an optimum daylighting performance for a default room in the same location by changing the envelope WWR, the second phase proved that Parans integrated system can be highly optimized. 
Two variables are studied in the parametric model, first the count of Parans lighting fixtures in the given space, secondly the illuminance power per fixture. The output for the parametric model was overall energy savings and daylight performance in the space. Simulations ran for several iterations till the optimum solution at 3 fixtures reaches relatively improved "daylighting distribution" that exceeds "LEED v4" criteria and passes "IES daylight availability standards".

This developed design is predicted to decrease the annual cooling load that is contributed for by heat transferred through building envelope representing $80 \%$ of total annual energy use compared to normal over-ground buildings. The decreased energy consumption results in total savings of 200 $\mathrm{kWh} / \mathrm{m} 2$ annually and decreasing the $\mathrm{CO}^{2}$ emissions monthly by $500-600 \mathrm{~kg}$ per unit. The developed optimization methodology successfully proved the efficiency of Parans lighting systems to provide $20 \%$ better daylight autonomy and 50\% less visual discomfort by omitting over-lit areas and providing a harmonized space lighting scheme. The proposed design optimization concept will encourage a diversity of underground space design alternatives, while enhancing the energy saving performance. Future research includes further development of the underground dwelling concept in the study area along with whole building simulations to study the energy performance toward a zero carbon target. Future application of the developed multi-objective optimization methodology can assist in the production of optimized lighting and thermal solutions and design guidelines for underground buildings. Design and optimization with the studied algorithm is 
$80 \%$ faster than default manual calculation techniques and consequently, more accurate.

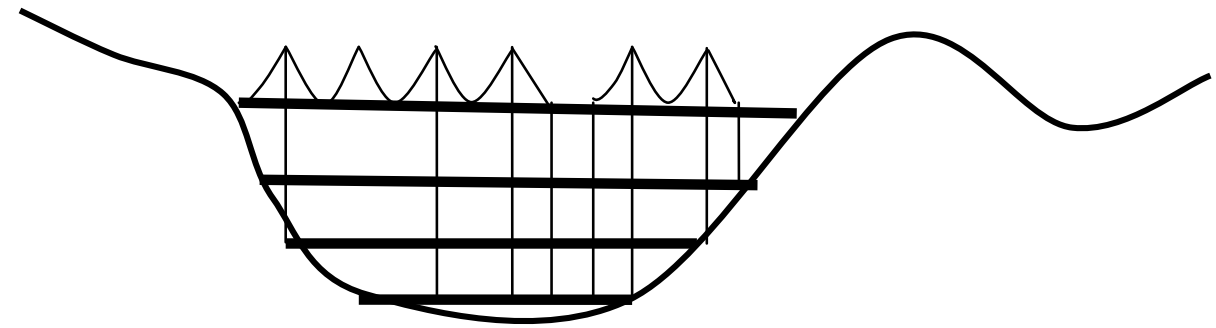

Fig. (19): THE Valley of with new residential floors and tents on the top (Researcher)

Regarding the proposed project cost estimate, it is recommended to perform a future detailed cost analysis study to reach a more accurate assessment for decision makers. Based on section view, fig (19) illustrates the current proposed sites in Mina and Arafat valleys are construction ready, without the need for additional excavation works. The proposal is based on the rapid constructible light weight steel structures, water-resistant assembled washrooms and internal light fabric partitions (same material utilized in the current tents). According to published research, this construction typology decreases construction and maintenance costs by $30 \%$, while minimizing the carbon footprint compared to regular concrete and brick construction.

\section{REFERENCES}

Sahih Bukhari-hadith No 732-733, No 2941-2944, No 732-733.

Haykal, M. H.(1994): The Life of Muhammad. The Other Press. p. 29.

Peters, F. E. (1994): The Hajj: The Muslim Pilgrimage to Mecca and the Holy Places. 
Juan, E. Campo, ed. (2009): Encyclopedia of Islam. Facts on File. p. 282.

Long, David E. (1979): The Hajj Today: A Survey of the Contemporary Pilgrimage to Makkah. p. 19.

"Hajj". Royal Embassy of Saudi Arabia. Retrieved 12 ${ }^{\text {th }}$, August, 2014.

Ministry of Pilgrimage releases Hajj statistics". Royal Embassy of Saudi Arabia. 1996-04-19.

Hajj pilgrimage 2011 by numbers: Telegraph. $3^{\text {rd }}$, November, 2011.

Hajj stampede: Saudis face growing criticism over deaths". BBC. $25^{\text {th }}$, September, 2015.

Sue Roaf, Manuel Fuentes, Stephanie Thomas. (2001). Ecohouse: a design guide. Architectural Press.

Shao, L. \& Riffat, S. B. (2000): "Day lighting using light pipes and its integration with solar heating and natural ventilation", Lighting Research and Technology, 323

Swift, P. D. \& Smith, G. B. (1995): "Cylindrical mirror light pipes", Solar Energy Materials and Solar Cells, 362

Zhang, X.; Muneer, T. \& Kubie,, J. (2002) "A design guide for performance assessment of solar light-pipes", Lighting Research and Technology, 342

U.S. DOE. Energy-Efficient Window Performance and Selection, p15.

El-Ghazi, Y.; Wagdy, A.; Mohamed, S. \& Hassan, A. (2014): Daylighting Driven Design: Optimizing Kaleidocycle façade for hot arid climate, proceedings of Fifth German-Austrian IBPSA Conference RWTH Aachen University. 314-321.

Long, Matthew (2011): Islamic Beliefs, Practices, and Cultures. Marshall Cavendish Corporation. p. 86.

Nigosian, S. A. (2004): Islam: Its History, Teaching, and Practices. Indiana: Indiana University Press. p. 110.

Katz, Andrew (16 ${ }^{\text {th }}$, October, 2013): "As the Hajj Unfolds in Saudi Arabia, A Deep Look Inside the Battle Against MERS". Time. Retrieved $8^{\text {th }}$, November, 2014. 
Armstrong, Karen (2002): Islam, A Short History. Modern Library Chronicles (Revised Updated ed.). Modern Library. pp. 10-12.

New Jersey: Princeton University Press. pp. 4-7.

Sterner, C. (2014): Measuring Daylight: Dynamic Daylighting Metrics \& What They Mean for Designers.

Coley, D., C. J. (1997): An artificial intelligence approach to the prediction of natural lighting levels. Building and Environment.

Day, M. (2009, June 01): Rhino Grasshopper. Retrieved June $5^{\text {th }}$, 2015, from AEC22.Gasiu, A., \& Reinhart, C. F. (2008). Current Daylighting Design Practice: A Survey. 36(2).

IES. (2012): Spatial daylight autonomy (sDA) and annual sunlight exposure (ASE). 24.NY: IES. LM-83-12. Lighting Measurement \#83.

Lagios, K.; Niemasz, J. \& Reinhart, C. F. (2010): Animated Building Performance Simulation (ABPS)-Linking Rhinoceros/ Grasshopper With Radiance/Daysim. SimBuild. New York City. 26. McNeel, R. (2010). Grasshopper - Generative Modeling with Rhino. Retrieved June, $24^{\text {th }}, 2014$, from McNeel North America, Seattle, USA.: http://www.grasshopper3d.com/

Ramos, G., \& Ghisi, E. (2010): Analysis of daylight calculated using the EnergyPlus program. Renewable and Sustainable Energy Reviews, 14(7), 1948-58.

Reinhart, C. F. \& Wienold, J. (2011): The daylighting dashboard -A simulation-based design analysis for daylit spaces. Building and Environment.

Reinhart, C. F.; Mardaljevic, J. \& Rogers, Z. (2006): Dynamic Daylight Performance Metrics for Sustainable Building Design. Leukos, 3, pp. 7-31.

Reinhart, C.; Lagios, K. \& Niemasz, J. (2011): DIVA for Rhino Version 2.0.

Retrieved June 10, 2014, from http://www.diva-for-rhino.com/

USGBC. (2013): LEED Reference Guide for Building Design and Construction v4. USGBC. Washington, D.C. 2013. 
Torres, Santiago, L. S. \& Yuzo (2007): Façade design optimization for daylight with a simple genetic algorithm. Building Simulation.

www.gelighting.com (2003) "Home lighting, lighting solution centre", Online product.

www.solaglobal.com (2003) "Solatube, the miracle skylight", online product information.

www.monodraught.co.uk (2003) "Sun Pipe", online product .

www.housing.sc.edu/westquadgo.asp.

www.newbuildings.org.

www.innovativedesign.net.

www.wascoskylights.com.

http://en .wikipedia.org/wiki/hajj\#.

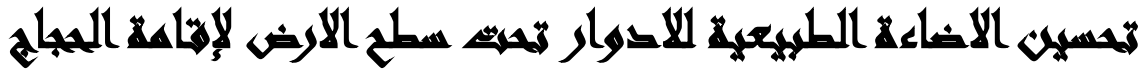

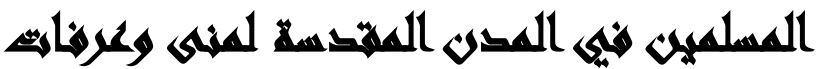

[?]

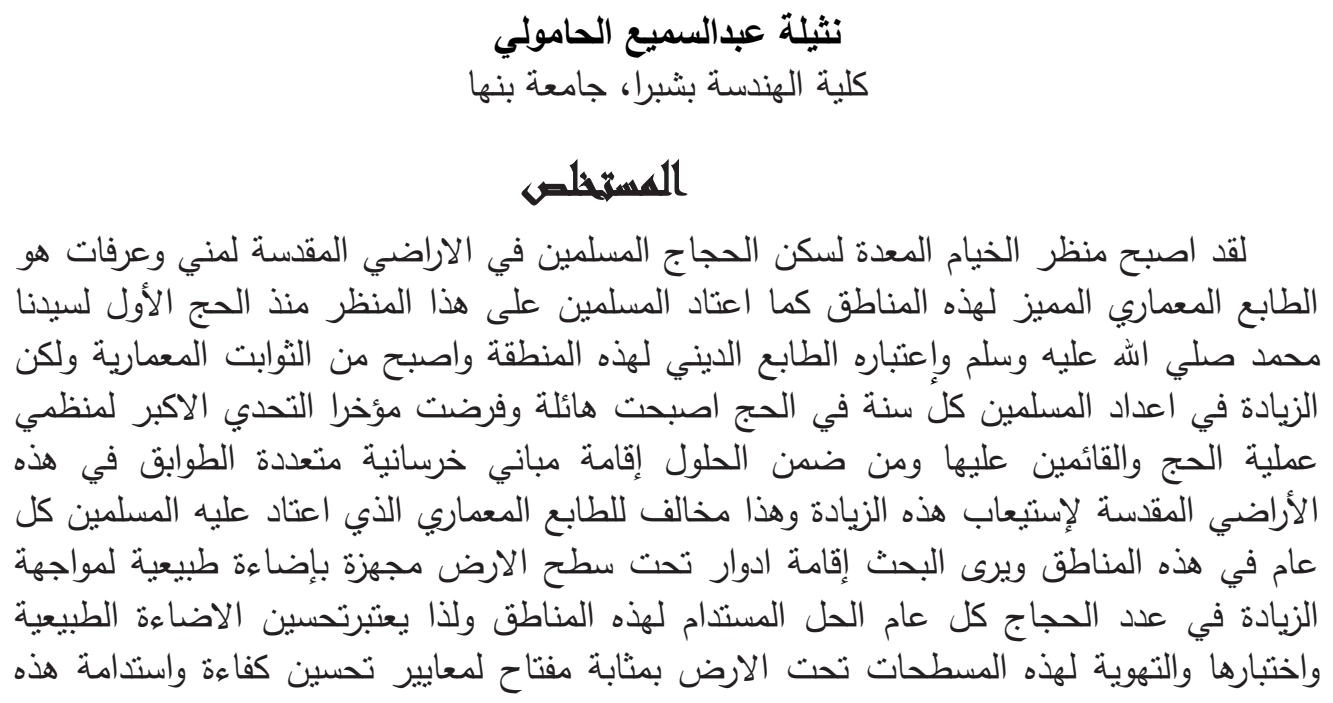


المناطق في توفير السكن المناسب للحجاج في مسطحات سكنية علي هيئة ادوار متعددة تحت

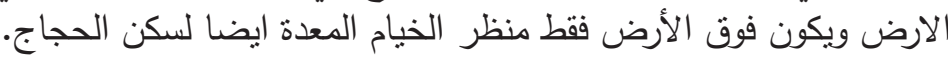

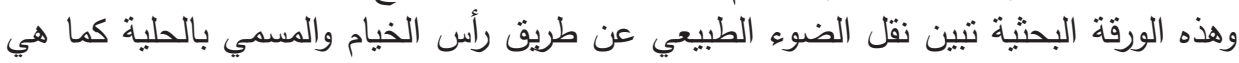

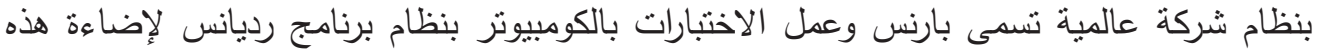
المساحات واثثت البحث توافقها مع معايير (الليد الاصدار الرابع) وتقليل انبعاثية ثاني اكسيد الكربون

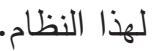

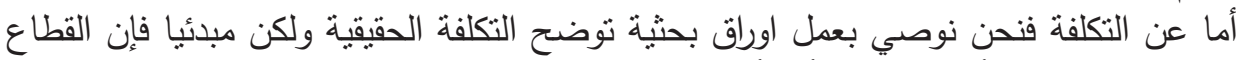

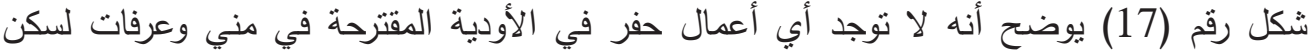

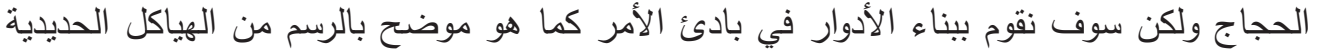

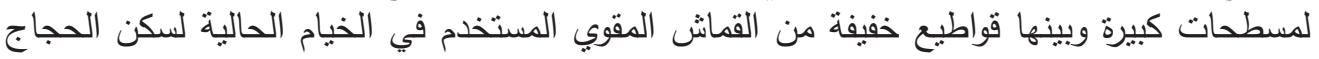

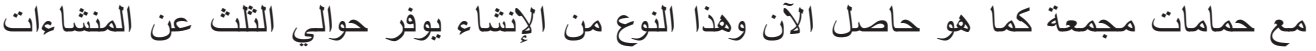
القائمة فوق سطح الأرض من الخرسانة والطوب العادي. 